Grant H. Lundberg

University of Kansas

\title{
Preliminary Report on Dialectological Fieldwork in Haloze, Slovenia
}

Prispevek prikazuje osnovne fonološke podatke dveh haloških govorov. Gorenjski Vrh predstavlja govor iz vzhodnih Haloz, Belavšek pa iz osrednjih. Na osnovi podatkov avtor podaja kratko skico zgodovinskega izvora teh narečnih sistemov, z njihovo razčlembo pa predlaga novo klasifikacijo haloškega narečja glede na sosednja.

This article presents a basic phonological description of two representative Haloze village dialects, one from the east, Gorenjski Vrh, and one from the center, Belavšek. This data is then used in a brief discussion of the historical provenience of these dialect systems. An alternative classification of Haloze in relation to its surrounding dialects is proposed.

\section{Introduction}

The Slovene language is one of the smallest of the Slavic family. It is spoken by somewhat more than two million people, and yet it has one of the most complex and variegated dialect maps in Europe. Notwithstanding the difficulties involved in documenting and analyzing such a diverse dialect system, most of the major pieces to this puzzle are in place (Ramovš 1935, Rigler 1963). Still, there are some holes in the Slovene dialect picture which are the result of either a lack of information or partially ambiguous descriptions. One such gap is the dialect area of Haloze, a small, hilly region on Slovenia's eastern border. Because it is located on the periphery of the Slovene speaking world, a position where, typologically, one expects to find archaisms, Haloze is potentially a very rich area in terms of dialectology and historical linguistics. The intent of this paper is to provide a basic phonemic description of two representative Haloze village dialects, one from the east, Gorenjski Vrh, and one from the center, Belavšek. This data will then be used in a brief discussion of the historical provenience of these dialect systems. ${ }^{1}$

\subsection{Location and Historical Background}

Haloze is located directly to the south of Ptuj. In fact, the road which connects Ptuj and Zagreb runs through the geographic center of Haloze. Its northern border is defined by the Dravinja and Drava rivers, and on its eastern and southern sides Haloze is delineated by the Slovene-Croatian national frontier. The western part of

\footnotetext{
${ }^{1}$ The data for these dialect descriptions come from the author's fieldwork in Slovenia from January 1997 to August 1998. This research was supported by grants and fellowships from the Slovene Ministry of Education and Sports, the National Security Education Program, the International Research and Exchanges Board and a Fulbright-Hays Dissertation Research Fellowship. For all of her help and advice, especially in the early stages of my fieldwork, I am grateful to Prof. Zinka Zorko of the University of Maribor. Finally, I would like to thank Prof. Marc L.
} 
Haloze runs south from Makole along the Jelovški stream to Donačka mountain. ${ }^{2}$ At its widest point in the west, Haloze covers about ten kilometers from the border to the Dravinja, but in the east it is only six kilometers wide. From Goričak in the east to Makole in the west it is just over thirty kilometers as the crow flies.

The hills of Haloze, which are covered with vineyards, are the most distinctive geographic feature of the area, and they grow progressively higher from the north-east to the south-west, so that in the east there is only a political and national border between Slovenia and Croatia, but in the south-west the line of mountains between Boč, Rogaška mountain and Macelj, all of which are from 700-800 meters in elevation, makes up a significant geographic as well as political border between the two countries.

Although Haloze has been populated from at least the Late Bronze Age, there is only sparse historical information on the region. It is known that the Slavic settlers began entering this area some time near the end of the sixth century, and it is likely that they learned viticulture from the Romance speaking population that preceded them. Beyond this the early feudal period is exceptionally dark.

Most of the information that helps to define which church and state centers had control over these lands is indirect. One such piece of information is Charlemagne's edict of 811 that the Drava was to be the dividing line between the Salzburg and the Aquileia Patriarchates. This made Haloze the eastern boundary of the Aquileian Patriarch's control. It is also known that in the very early feudal period most of Haloze was under the feudal control of Ptuj.

This situation, especially for western and central Haloze continued largely unchanged until the mid-nineteenth century. The people of most of Haloze were directed, religiously and politically, from Aquileia, Ptuj, Štatenberg and Celje (Bračič 1982: 27). The situation is slightly different for eastern Haloze where the church and state boundaries were less stable. This is due partly to the fact that the Hungarians annexed eastern Haloze in 907 and did not lose control of it until Frederich of Ptuj reclaimed the Ormož region on Easter 1200. At the same time the castle Tranbek, located near the present day village of Dravinjski Vrh, took back the lands of eastern Haloze and probably the castle Borl (Bračič 1967: 57).

From the mid-thirteenth century on most of eastern and part of central Haloze was controlled from Borl, and the Slovene state and ethnic borders developed much as they are today. Unfortunately, some time after 1927, all of the land registers of the castle Borl disappeared, so almost nothing is known about the demographics of eastern Haloze during the feudal period. It is also not clear what the boundaries of church government were during the time of Hungarian control of this region. It is known, however, that at least the villages around the north-eastern center of Zavrč were under the control of the Zagreb diocese until at least 1545 (62).

Greenberg of the University of Kansas for his invaluable academic guidance as well as for his support and encouragement during the often very difficult process of doing fieldwork. I am also grateful to an anonymous referee who gave several helpful remarks on a later draft of this paper.

${ }^{2}$ This western boundary of Haloze defines the geographical borders of the region (Bračič 1967). The western dialect border cannot be clearly defined at this time because of lack of information. 
There has never been one major gathering point in Haloze. Even today when people of this area travel for employment or shopping they go either toward Zagreb or Ptuj and Maribor. There are, of course, local centers. In eastern and central Haloze, the two sub-dialects that are dealt with in this paper, there are four local centers, one on each river: Zavrč on the Drava, Cirkulane on the Bela (the villages that surround these two make up eastern Haloze), Leskovec on the Psičina and Podlehnik on the Rogatnica (the villages that surround Leskovec and those to the east of Podlehnik ${ }^{3}$ make up central Haloze) (see figure 1).

\section{Figure 1: Map of Haloze}

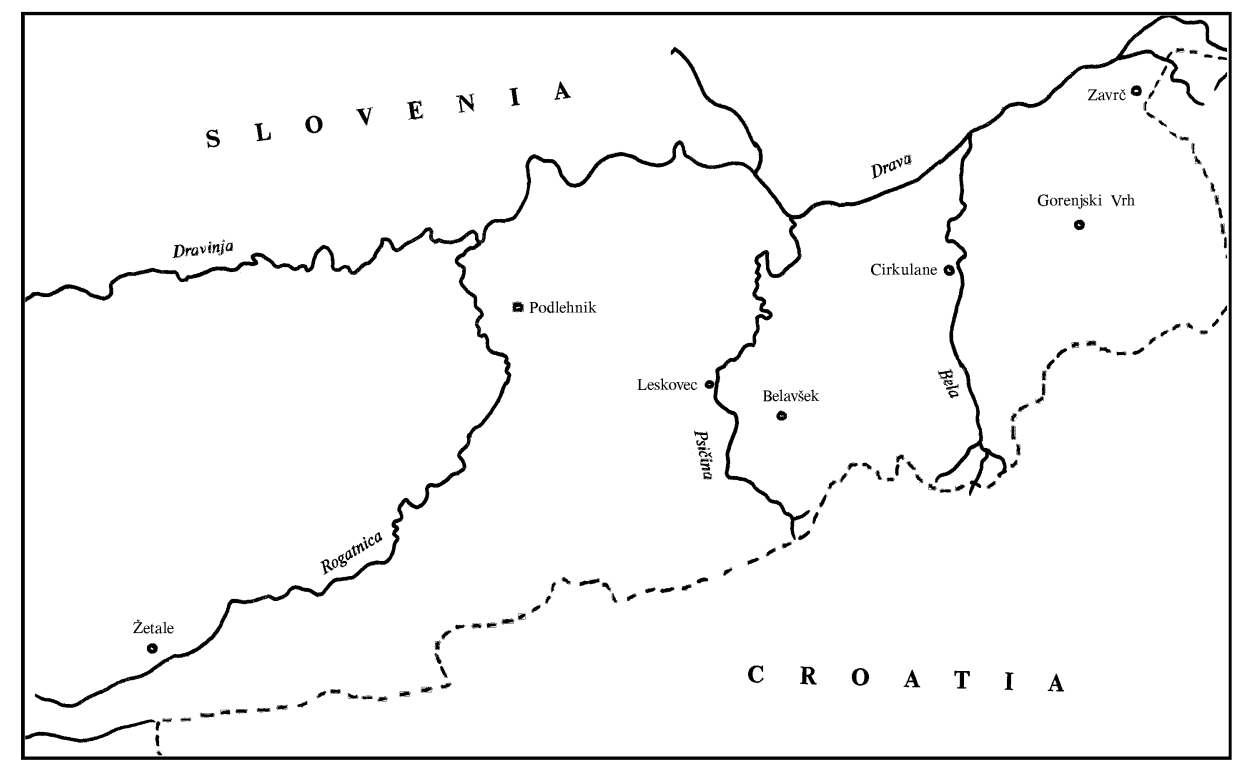

\section{Previous Descriptions of the Haloze Dialect}

As regards the speech of the people of Haloze relatively little is known. The dialect is only briefly mentioned by Ramovš (1935: 181). Basing his judgment on only a few forms, he places it in the Pannonian dialect group because of the similarities he sees to the dialect of Prlekija. Rigler does not mention Haloze specifically in his 1963 contribution, but his dialect map follows Ramovš by placing it in the Pannonian group (45). Based on his dialect map, one might expect to find Haloze mentioned in Rigler's later article on Pannonian vocalic developments (1986a). This, however, is not the case. Rigler simply indicates that Haloze can no longer be considered a part of the Pannonian group (117), and he cites Kolarič's 1964 article as the support for this statement. This contribution by Kolarič as well as two important publications by Zinka Zorko $(1991,1993)$ have added vital data to what is known about Haloze, but the particular emphasis of this new research leaves some questions unanswered.

\footnotetext{
${ }^{3}$ The isoglosses west of Podlehnik and east of Žetale which define the boundary between central and western Haloze cannot be specifically indicated because of lack of any descriptions from this area.
} 
One limitation of Kolaričs work is that he rarely indicates the village provenience of the forms he reports. He indicates only that the material comes from recordings made of four students at the Ptuj Gymnasium, three of whom were noticeably influenced by the standard language, and two of whom had been raised by parents from outside of Haloze. The lack of specifics about the origin of his material is compounded by the fact that he often lists multiple reflexes of a given PSl. phoneme without elaboration. For example, he records four different reflexes of the PSl. front nasal without any information about their distribution: $e: i, e, e, e$ : $e:$ (398). Based on this information, it is difficult to tell if Haloze is undergoing some sort of phonetic change or if there are perhaps several smaller dialects within the borders of Haloze. It may also be that some of this variation is due to influence from the standard language.

Zorko's presentation of material is more helpful and specific than that of Kolarič, although there are some open questions in her discussion of Haloze (see Greenberg 1992: 79). She deals with the complex dialect situation in Haloze by defining three loosely classified sub-dialects which she terms "eastern," "central" and "western" Haloze. According to Zorko's data (1993: 205), this three-way classification of Haloze village dialects is based primarily on three isoglosses, the exact locations of which are not yet apparent (see figure 2). These isoglosses are (1) a diphthongal as opposed to a monophthongal vocalic system, (2) retention of quantity distinctions and (3) word-level tonemic oppositions.

\section{Figure 2: Zorko's classification of Haloze sub-dialects}

\begin{tabular}{lcccc}
\hline & diphthongal & quantity oppositions & tonemic oppositions \\
\hline Eastern Haloze & - & + & + \\
Central Haloze & + & + & $+/-$ \\
Western Haloze & + & - & - \\
\hline
\end{tabular}

As mentioned above, Zorko's description of the Haloze dialects is informative, but there are some interesting issues for further inquiry, particularly in eastern Haloze. For example, Zorko claims that a distinctive system of tonal oppositions has been preserved here and that this distinction is only retained on short accented syllables (1991: 55). In other words, she believes she has found some examples in which original Slavic acute, neo-acute and some later retractions have retained a short rising tone. This was only observed in eastern Haloze and parts of central Haloze. Although this is unexpected typologically and is surprising in terms of dialect geography (all the Pannonian and Styrian dialects that surround it have lost distinctive pitch), this question requires further investigation, because Haloze is in close proximity to the Kajkavian Zagorje dialect which does retain distinctive tonal oppositions (e.g., Bednja, see Jedvaj 1956).

\section{Phonemic System}

For the purposes of this paper, we will use Zorko's basic three way classification of Haloze village dialects as a starting point for a discussion of the consonantal and vocalic systems of Gorenjski Vrh (several kilometers south of Zavrč) and Belavšek (several kilometers east of Zgornji Leskovec). The village dialect of Gorenjski Vrh represents a type found throughout eastern Haloze. This includes the villages 
around Zavrč and Cirkulane. Belavšek is representative of dialects throughout central Haloze which includes the villages around Zgornji Leskovec and those to the east of Podlehnik.

\subsection{Prosody}

Both eastern and central Haloze have vocalic systems in which all distinctions of word-level prosody are realized in the accented syllable and in which the accent is free to fall on any syllable of the word. Both systems have distinctive quantity, b'rat 'brother', b'ra:t (sup.) 'to pick' (Gorenjski Vrh), although that quantity, still distinctive, carries less functional load in Belavšek because it is almost always accompanied by a quality distinction, 'dẹlati (inf.) 'to work', 'dä: îlaš (2nd pers. sg.) 'you work' (Belavšek). ${ }^{4}$

Though the systems are similar, there are important difference as well. One example of this is found in the advancement of the PSl. circumflex. Eastern Haloze appears to have carried this process of advancement through on a much more limited scale than in central Haloze, where the process was quite regular. For example, in Gorenjski Vrh we find 'me:so 'meat', č're:vo 'gut', g'la:vu (acc. sg. fem.) 'head', but also ko'ko:ši 'chicken'. These examples from eastern Haloze show that in certain phonetic environments, for example, a word with an open second syllable, the PSI. circumflex failed to advance, but if the second syllable was closed, advancement took place. In Belavšek (central Haloze), on the other hand, we see mę'so:u, čres'vo:u, gla'vo:u, as well as ku'ko:ǔs, indicating that circumflex advancement took place in both of these environments (on the advancement hierarchy in Slovene and Kajkavian dialects see Greenberg 1992). ${ }^{5}$

\subsection{Tonemic Oppositions}

As mentioned above, Zinka Zorko has made some interesting claims about tonal oppositions in Haloze. "Na vzhodu in deloma v osredju je ohranjena še opozicija med visoko (cirkumfleks) in nizko intonacijo (akut). Nizka intonacija je možna le na kratko naglašenem zlogu, v katerem je samoglasnik refleks starega ali novega akuta ali pa akuta na sekundarno naglašenem zlogu" ('In the east and part of the center the opposition between high [circumflex] and low [acute] intonation is still retained. Low intonation can occur only on short stressed syllables in which the vowel is the reflex of the old or new acute or from secondary retraction') (Zorko 1993: 205). Prof. Zorko's statement is intriguing, especially when compared to the often quoted anecdotal evaluation of Haloze speech by J. Pajek in Zora 1875. His claim is that the voice of a speaker of the Haloze dialect jumps up high every third or fourth word and then goes down again (from Kolarič 1964). This, of course, could be understood in many ways, but one possibility is that Zorko and Pajek are both evaluating the same phenomenon, i.e., sentence - not word-intonation.

Additional support for this idea is based on the preliminary results of a spectrograph and pitch frequency analysis performed by the author of this paper on

\footnotetext{
${ }^{4}$ All examples, unless otherwise stated, are from the author's notes and recordings while in the field.

${ }^{5} \mathrm{~A}$ fuller treatment of the problem of circumflex advancement in Haloze is planned for a later paper.
} 
short accented vowels from the central Haloze village dialect of Trdobojci has essentially the same phonemic system as Belavšek. ${ }^{6}$ In this study only short accented syllables were examined in an attempt to test Zorko's claim that distinctive pitch is retained only in short syllables.

The analysis focused on the reflexes of PSl. acute, neo-acutes on etymologically short vowels and secondary retractions on to originally short vowels. All of the forms evaluated were taken from sentence medial position. The forms tested thus far indicate that there is a short rising tone contained within the accented syllable on these forms. For example, the pitch contour for one example of the form 'reku 'he said' starts from the beginning of the accented vowel at $275.6 \mathrm{~Hz}$ and peaks at the end of the accented vowel at $306 \mathrm{~Hz}$. Then the frequency falls steadily through the second vowel. The same kind of pitch contour is seen on the accented syllable of 'poznate 'you know'. For this form the accented vowel begins at $200.45 \mathrm{~Hz}$. It dips to $193.42 \mathrm{~Hz}$ and then peaks at the end of the accented vowel at $208.02 \mathrm{~Hz}$. The frequency then falls through the following two vowels to $159.78 \mathrm{~Hz}$ at the end of the word. $^{7}$ The preliminary results also show that this pitch contour is neutralized if the word falls in sentence initial or sentence final position. For example, in sentence-final position, the word 'họdiš 'you walk' has a steady fall in frequency from $190 \mathrm{~Hz}$ at the beginning of the accented vowel to $160 \mathrm{~Hz}$ at the end of the word. Having said this, it must be noted that the existence of this feature does not make it phonemic or meaning distinguishing. In fact, in Trdobojci at least it seems to be a redundant phonetic feature because it is in complementary distribution with length. Rising tone on short accented vowels is predictable because there is no other source for short vowels. This situation has come about because circumflex on etymologically short vowels has lengthened in Haloze.

This analysis is also consistent with the data provided by Zorko in her discussion of rising tone in Haloze (1993). The only examples of short accented syllables provided are those on which she expects a rising tone because the forms contain reflexes of the PSl. acute, neo-acute and secondary retraction onto etymologically short vowels. Other etymologically short vowels have lengthened, 'de:n 'day', 'nọ: ̌ 'night', and Zorko gives no contrastive examples of short non-rising forms. This

${ }^{6}$ This analysis was performed on software developed by Speech Technology Research, Ltd, Multi-Speech Signal Analysis Workstation, Model 3700, Version 1.20. in the Phonetics Laboratory at the Department of Linguistics, University of Kansas.

${ }^{7} \mathrm{~A}$ fuller analysis of this question is planned for a future paper. This discussion will also include material from the eastern village dialect of Hrastovec. This dialect appears to have innovated an interesting system of word intonation in which every accented form has rising pitch. Original quantity oppositions are retained except in sentence or phrase final position, where the accented vowel is long. The pitch contour is such that the tone peaks at the end of the accented syllable, and then trails off to the end of the word. Some examples of this intonation pattern are listed below.

[Pa tístę škạ́fę smọ brạ́:li, pa pụ́tȩ sọ mệ:li] ‘And we gathered those pails, and they had wooden tubs'.

[Sọ zlọ́żili f tístę obrộ:čę 'They put it in those hoops'.

[Mọ́škị sọ mệ:li kọ́:šę] ‘The men had baskets'.

[Pa smọ nọsí:li na vọ́:s] 'And we carried it on wagons'.

[Gịbạ́:ncę smọ jệ:li] 'We ate cakes'.

[Za ộbịt smọ mẹ́:lị kíslọ zé:lę] 'For dinner we had sour cabbage'. 
means that there can be no distinctive tonemic opposition on short vowels. Tone in eastern Haloze appears to be like the phonetic feature of word final devoicing in many Slavic languages or the aspiration which accompanies word initial voiceless obstruents in English. These features are predictable from their environment. ${ }^{8}$

\subsection{Consonants}

\subsubsection{Obstruents}

$\begin{array}{llll}p & t & & k \\ b & d & & g \\ f & s & \check{s} & h \\ & z & \check{z} & \\ & c & \check{c} & \end{array}$

\subsubsection{Resonants}

$\begin{array}{lll}m & n & \\ & l & \\ & & r \\ & & j\end{array}$

(E. Haloze also $j \neq \tilde{J}$ )

The system of consonantal phonemes is basically uniform in the dialects of eastern and central Haloze. All voiced obstruents, including /v/, are voiceless before a following voiceless obstruents and at the end of a word, 'bo:uk 'God', 'bo:ugęc 'Jesus', 'nuš - 'nužȩ 'knife', 'cẹrkȩf - 'cẹkvi 'church'. Voiceless obstruents are voiced when they are in the position before a voiced obstruent except $v$, 'grež du'mu: 'you go home', 'tvuj 'your'. Both areas have the development $* n$ ' $>j$ but with slightly different results. In the eastern dialects $\tilde{j}$ has not merged with $j$, but in the central dialects the merger has taken place, e.g., s'vi:ja 'pig' (Gorenjski Vrh), s'vị:ijja 'pig' (Belavšek). A palatalized $/ \mathrm{k} /$ can sometimes be heard in the word ' $k$ 'ẹdęn 'week'. Vocalic $l$ and $n$ appear in Haloze under very restricted conditions. The $l$ is found in several German borrowings, f'ro:uštikl 'breakfast', 'mantl 'coat'. The $n$ is found where a reduced vowel has been dropped, 'osñdessȩt 'eighteen', 'sändęsȩt 'seventeen'. Historically soft $* l$ ' and * $n$ ' have both hardened, 'ogęn 'fire', k'ra:l 'king'. The development of $*-m>-n$ in final position is found in Haloze, 'dä:illan 'I am working', 'sin (adv.) 'toward me'. In at least one word we can see $* m>v$ in the position before $n$, v'nugo 'much'. In both eastern and central Haloze the combination $u m>h m$,

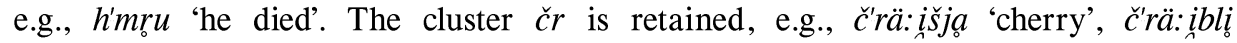
'boots'. In word-final position following a high front or mid vowel such as $i$ or $\ddot{u}$, the phoneme $/ \mathrm{h} /$ is optionally realized as $/ \check{\mathbf{s}} /, k^{\prime}$ rüš 'bread', op 'šästiš 'at six'. In word-initial position $\ddot{u}>v \ddot{u}$, e.g., 'vüra 'hour', 'vü:ista 'mouth'. The cluster šč is realized as $\check{s}$, e.g., 'i: $i$ išş̌s 'you look'. The cluster $h \check{c}$ has also become simplified to $\check{s}$, e.g., 'niše 'no one', except in the word h'čẹ:r 'daughter'.

${ }^{8}$ This discussion must remain tentative at present because we lack some important information. We do not yet know what the pitch contour is on long vowels because this initial study focused on Zorko's claim that distinctive pitch in eastern Haloze is retained only in short syllables. More research is needed on the status of long syllables in this dialect. 


\subsection{Vocalic Systems ${ }^{9}$}

\subsubsection{Gorenjski Vrh (eastern)}

\section{Long accented}

$i$

$\begin{array}{llll} & \ddot{u}: & & \\ e: & & & \\ & & & \end{array}$

\section{Examples}

(Glosses are given only if the corresponding standard Slovene form has a different meaning or if the formal correspondence to Slovene is not clear.)

$i: \leftarrow * i$ : - 'si:nȩ (acc. sg. masc.) 'sons', 'vi:dimo, glẹ'di:n (1st pers. sg.) 'to watch', glę'di:š, glȩ'di:mo, ko'si:t (sup.), po'bi:rat (sup.), ži'vi: (3rd pers. sg.), gu'či:mo 'to talk', 'pi:li, 'pi:ję, sa'di: (3rd pers. sg.), sa'di:la, okra'si:mo, nọ'si:li, b'li: (l-pcp., masc. pl. pl.) 'to be', 'bi:la (l-pcp., fem. sg.), 'mi:slin (1st pers. sg.), zas'pi:n (1st pers. sg.), 'ti:kva 'squash', 'zi:mu (acc. sg. fem.), 'pri:nas 'among us', 'i:jęš (2nd pers. sg.) 'to go', s'vi:ja 'pig', s'vi:jọon (instr. sg. fem.), 'vi:sọko

$e: \leftarrow * e ̌: ~-~ b ' r e ̣: k$ 'hill', 'lẹ:s, ó'bẹ:sili, óbẹ:simo, d'rẹ:vo, 'bẹ:lu (adj., acc. sg. fem.), 'bẹ:le (gen. sg. fem.), nam'le:li, s'vẹ:t, 'cẹ:li (adj., nom. sg. masc.), 'mẹ:sęc, nap're:dęk, ži've:li, z've:zda, 'le:t (gen. pl. neut.) 'year'

$\leftarrow *$ : - 'dẹ:n 'day', 'vẹ:s 'village'

$\leftarrow * e:-j e s ' s e: n$

$e: \leftarrow{ }^{*} e$ : - 'pe:t, 'me:so 'meat', dȩ'se:t, s've:ti, zag'le:do (l-pcp., masc. sg.) 'to watch', zag'le:dala, 'te:ško, 'je:zik, v're:di 'okay', gọ've:dina

$\leftarrow$ *e: - vȩ'če:r, 'pe:či (gen. sg. fem.), 'še:st, kọ're:̃̃e (acc. pl. fem.) 'carrot'

$a: \leftarrow * a:$ - g'la:va, g'la:vu (acc. sg. fem.), 'gra:t, b'ra: je 'picking', o'ra:t (u'ra:t) (sup.) 'to plow', v'la:k, b'ra:t (sup.), b'ra:li, st'ra:ni (gen. sg. fem.), op'ra:lo (l-pcp., neut. sg.), kợla:č, t'ra:va, t'ra:vi (dat. sg. fem.), s'pa:t (sup.), 'pa:o ('po:) (l-pcp., masc. sg.) 'to fall', 'ra:zmesš (2nd pers. sg.) 'to understand', 'kra:pci 'meat or jelly-filled pastry'

$o: \leftarrow * o:$ - 'bo:k 'God', b'lọ: (l-pcp., neut. sg.) 'to be', kọ'kọ:ši, kọ'žo:la (ku'žo:la) 'bean', g'nọ:j, 'dọ:bili, prȩ'vọ:za (gen., masc., sg.), ọt'rọ:k (gen. pl. masc.), 'no: :̌

$\leftarrow *_{-} V l \zeta-n a^{\prime} j o:$ ( $l$-pcp., masc. sg.) 'to eat', 'šo: (l-pcp., masc. sg.) 'went'

$\leftarrow *_{\text {-ov\# }}-d u^{\prime} m o:$ : (adv.)

$\leftarrow{ }^{*} Q$ : - 'bo:: ̌̌ (fut., 2nd pers. sg.) 'to be', k'lo:p, 'rọ:ka, 'mọ:̌̌, 'sọ:sịdi ('sọ:sȩdi) (nom. pl. masc.) 'neighbors', $d r^{\prime} g o: \check{c}$ 'again'

$u: \leftarrow * l:$ 'su:nces, 'vu:k

$\ddot{u}: \leftarrow * u$ : - 'lü:č, 'čü:k 'owl', 'lü:šimo 'to peel', 'kü:rȩ (nom. sg. fem.) 'chickens', opa'zü:jęn (1st pers. sg.), 'sü:šę (acc. pl. fem.)

${ }^{9}$ Two primary informants were chosen for both of the dialects described here. The criteria used in this selection were age, all were born before the Second World War, and how long they had lived in the dialect area, all were born and raised in Haloze within several kilometers of their present homes. 
$r: \leftarrow{ }^{*} r:$ - 'dr:vo, 'gr:do, na 'žr:ve (acc. pl. fem.) ‘žrne', 'to grind by hand', 'vr:h 'village'

\section{Short accented}

$i$

$$
\ddot{u}
$$

$u$

$e$

$\quad r$

$\ddot{a}$

$a$

Examples

$i \leftarrow{ }^{*} i-$ 'hiša, nọ'siti, 'mizu (acc. sg. fem.), 'biti 'to be', 'finkišta 'Pentecost', 'hitititi ('hitäti) 'hurry'

$e \leftarrow * \check{e}-n e^{\prime} d e ̣ l a, n e ̧$ 'dẹlu (acc. sg. fem.), 'delati, 'delo (nom. sg. neut.), 'lẹtọ, 'lẹta (gen. sg. neut.), b'ręza, ớrẹhę (acc. pl. masc.), 'rẹpa, sk'lẹda, z m'lekon (instr. sg. neut.), 'jẹsti, 'tẹdnę (acc. pl. masc.), 'dẹci (dat. sg., but with pl. meaning) 'children'

$\leftarrow$ *ə - 'mẹša 'mass', 'dẹ̌s, 'snexa 'daughter-in-law'

$e \leftarrow{ }^{*} e-n a^{\prime} r e t i$ 'to do', g'ledati, za'četi, g're (g're:) (3rd pers. sg.) 'to go'

$\leftarrow$ *e - 'nesẹn (1st pers. sg.), 'nebrȩn 'I cannot', 'sedęn 'seven', 'petruš 'parsley', 'mela 'flour', 'melę (gen. sg. fem.), 'zemla, 'sestra, 'devęt (also dẹ'vet), k'met, 'reko (l-pcp., masc. sg.), 'rečęen (1st pers. sg.) 'to say', 'nesẹn (1st pers. sg.), 'klecęnprot 'fruit cake'

$\leftarrow * \check{e}-$ 'dečko (nom. sg. masc.) 'boy', 'dedęk

$a \leftarrow *^{*} a-b^{\prime} r a t$, 'jabušnica 'apple wine', 'kanta 'jug', 'jako 'very', 'šalca 'pot', g'rabah (loc. pl. fem.) 'valley', b'rati 'to pick', 'ladu (acc. sg. fem.) 'load', u'rati 'to plow', na 'ramah, 'čakati, 'kan 'to where', 'jace (acc. pl. fem.) 'egg', $k$ 'nan 'to us', 'fare (gen. sg. fem.), 'kaša, 'začiba 'začimba 'zaseka'

$o \leftarrow *_{Q} Q-z ̌ z ̧ e^{\prime} l o d e ̨ c$, 'moka, 'moku (acc. sg. fem.), 'goba, 'toča, 'so

$\leftarrow{ }^{*} o-$ 'bop 'pea', 'človilk, 'koža, 'poznao (l-pcp., masc. sg.), 'dobra (adj., nom. sg. fem.), 'mọrš 'you must', 'mošst, 'opẹt 'again', 'konca (gen., masc., sg.), kọ̌s, 'ọbit 'lunch', 'vọda, 'doma ('duma) 'at home', 'komaj ('kumaj) 'hardly'

$u \leftarrow * l-$ 'pun 'full', 'tukla 'apple wine'

$\ddot{u} \leftarrow * u-$ 'tü 'here', k'rüxa (gen., masc., sg.), s k'rüxọn (instr. sg. masc.), 'šüma 'woods', 'vüra 'hour', 'žüpa 'soup', 'pütę (acc. pl. fem.)

$\leftarrow$ *ə - 'vün 'out', 'vüzẹn 'Easter'

$r \leftarrow *_{r}-{ }^{\prime} z r n n o, ' h r b e ̨ t$

$\ddot{a} \leftarrow * \partial-' l a ̈ h k o$

\section{Unaccented}

$i$

i 


\section{Examples}

$i \leftarrow{ }^{*} i-o^{\prime} b e: s i l i$, ži'vi:, 'začiba, 'vi:din, hi'ti:n (1st pers. sg.) 'to hurry'

$\leftarrow *_{-u}-n a$ b're:gi (loc. sg. masc.), po 'mẹsti (dat. sg. neut.), na 'mo:sti (loc. sg. masc.), b'rati (dat. sg. masc.) 'brother'

$i \leftarrow * \check{e}-\check{c}^{\prime} l o v i \underline{k}$, 'obịt

$e \leftarrow *_{e}$ - 'devęt, 'ra:zrę̧t, glę'di:š, 'mẹ:sęc

$\leftarrow * e-v e ̨ ́ c e: r, n e ́ d e l a$, 'nesẹn

$\leftarrow *^{*}$ - 'dedęk, 'za:vęc

$a \leftarrow{ }^{*} a-k^{\prime} r a v a$, 'vọda, zag'le:dala (l-pcp., fem. sg.), g'la:va

$o \leftarrow{ }^{*} o-$ - 'me:so, 'gr:do, okra'si:mo, 'ọtrọ, op'ra:lo

$u \leftarrow * u-$ 'petruš, pus'titi

$\leftarrow *^{*} o-$ 'delu, 'kokuš, du'mọ:

$\leftarrow *_{Q}-$ 'mizu, g'la:vu

$\leftarrow{ }^{* l}-$ gu'ci:n (1st pers. sg.) 'to talk', 'jabuka (nom. sg. fem.) ('jabọka, 'jabọ̆nik)

$r \leftarrow * r-d r^{\prime} g o: \check{c}$

\subsubsection{Belavšek (central)}

\section{Long accented}

$i: i$

$e:$

$\ddot{a}: i$ $\ddot{u}: i$

o: $u_{1}$

$a:(\sim a:)$ $u$ :

$r:$

\section{Examples}

$i: i \leftarrow * i$ - s'vi::ija (nom. sg. fem.) 'pig', 'zi: ima, po'zi: imi, 'zi: it 'wall', 'si::in, b'li:i (l-pcp., masc. pl.) 'to be', 'bi: illa (l-pcp., fem. sg.), 'pi: ilil, 'vi: ino, 'ci:izzra 'bean',

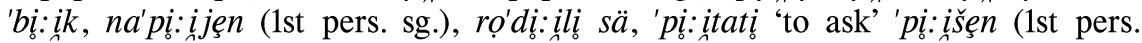

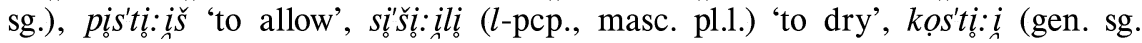
fem.), glẹ'dil: in (1st pers. sg.) 'to watch', goss'ti: ijja 'wedding, lệtti: in (1st pers. sg.) 'I run', ži i'vi: in (1st pers. sg.), ži'viı: imo

e: $\leftarrow$ *ę: - 'pe:t, ịm'ę:, g'lee:dali, 'pe:tęk, 'pẹ:st, go'vẹ:dịna, v'rẹ:di 'okay', grẹ:n (1st pers. sg.) 'to go', g're:mo, g're:du (3rd pers. pl.), 'te::ško, za'pe:stje 'palm'

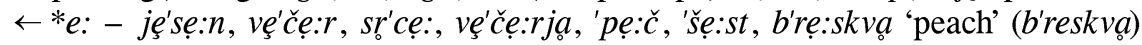

$\leftarrow *_{\partial}$ - 'dẹ:n ('dä:in) 'day', 'vẹ:s 'village', la'kẹ:t 'elbow', 'dẹ:vlaš (2nd pers. sg.) 'to put in', na'dẹ:vlan (1st pers. sg.), 'mẹ:šnick 'priest'

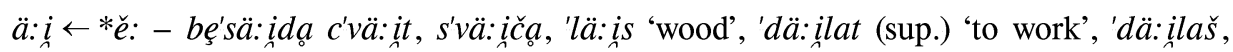
o'bä: ili íš 'to peel', 'bä: iži (imp.) 'to run', po 'tä: istti (dat. sg. neut.) 'dough',

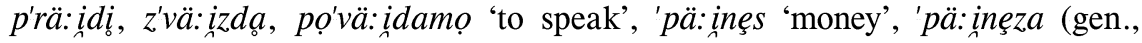
masc., sg.), č'rä:iñbli 'boots', 'bä:ilimimi (adj., instr. pl. masc.) 'white', 'sä:innca,

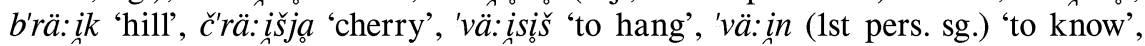
'vä: išn (2nd pers. sg.) 
a: $\quad{ }^{*} a:$ - g'ra:t, k'la:s, g'la:va, na g'la:vu (acc. sg. fem.), t'ra:va, s'pa:t (sup.), zas'pa:li, ka'za:lęc, v'ra:t, 'la:s, d'va:, st'va:r, h'ra:st, k'ra:l, ko'la:čc 'tort', 'za:čnäju (3rd pers. pl.) 'to begin', zȩ'ha:vla sä mi 'to yawn', pod'ga:na, b'ra:da, b'ra:de (gen. sg. fem.), 'za:vȩc

o: $\leftarrow^{*}{ }^{*} Q:$ - k'lo:up, 'zo:up 'tooth', 'po:ut 'path', gla'vo:u (acc. sg. fem.), vo'do:u, 'bo:uš (fut., 2 nd pers. sg.) 'to be', 'ro:uka 'hand', rọ'ko:u (acc. sg. fem.), ôk'ro:ungli 'circular', na'ro:ube (adv.) by mistake', 'so:usęt 'neighbor', v'rog:učȩ, 'so:ut 'barrel', 'go:usto 'thick', 'lo:uchi (3rd pers. sg.) 'to distinguish'

$\leftarrow * o:-b^{\prime} l o: u$ (l-pcp., neut. sg.) 'to be', 'bo:uk 'God', 'vo:us 'wagon', mę'so:u 'meat', 'ko:ust 'bone', ku'ko:uš 'chicken', 'po:ubrali, f'ro:uštikl 'breakfast', lẹ'po:u, 'po:uzzno 'late', o'ko:uli, 'go:ule (adv.) 'naked', ško:udi (3rd pers. sg.) 'to harm', ško:udla (l-pcp., fem. sg.), k'lo:uni (3rd pers. sg.) 'to leave to, to give', 'šo:ula 'school', nej nȩ 'bo:ugaš 'you do not obey', 'rog:uk 'horn', zla'to:u, 'šo:ul$n i$ 'shoes', 'gro:uzdję (nom. sg. neut.) 'grapes', na 'o:uko, 'do:ubu (l-pcp., masc. sg.) 'to receive' 'do:ubili (l-pcp., masc. pl.), ot'ro:uk (gen. pl. masc.) 'child'

$\leftarrow * a: N$ - 'lo:uni 'last year', s'ro:un 'shame', brat'ro:uñȩc, pi'jo:unęc, gì'bo:unca 'gibanica', st'ro:uni (loc. sg. fem.), 'side', 'ro:uno 'early'

$\leftarrow$ *V:lъ - sun 'po:u 'I fell', 'bo:un 'šo:u 'I will go', sun 'jo:u 'I ate'

$u \leftarrow * !:$ - 'vu:k 'wolf', 'du:k 'debt', 'žu:ti 'yellow', 'gu:t 'throat', 'du:go (adv.) 'long time'

$\leftarrow * N Q:-' m u: \check{s}$ 'husband'

$\leftarrow * N o$ : - 'nu:s 'nose', 'mu:č 'strength', 'nu:č 'night', 'nu:ga 'foot', z'vu:n 'bell', $g^{\prime} n u: j$ 'manure'

$\leftarrow{ }^{*}$-ov\# - du'mu: (adv.) 'toward home'

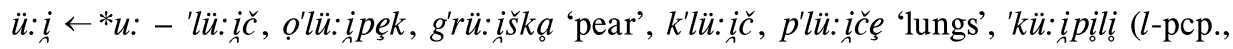
masc. pl.), 'kü:inpu (l-pcp., masc. sg.), 'vü: i্sta 'mouth', 'jü:innci, 'pü:invali ( l-pcp., masc. pl.) 'to build'

$r \quad \leftarrow *_{0}:-m_{r}: k a$ 'pickle', 'vr: $h$

\section{Short accented}

$i$

$\begin{array}{llllll} & & & & u & \\ & & & & & \\ & & & & & \\ & a & & & \end{array}$

\section{Examples}

$i \leftarrow *_{i}-$ krum'pir , krum'pịra (gen. sg. masc.), krum'pịre (acc. pl. masc.), 'sịr, 'sịra (gen. sg. masc.), 'hiša, 'hišu (acc. sg. fem.), 'hiše (gen. sg. fem.), 'miš, 'miš (gen. sg. fem.), 'cvirȩn 'thread', kọ'ritọ 'trough', 'rit, 'ritati 'to kick', 'nič, 'miję (pron., 1st pers. masc. du.), 'vijes (pron., 2p., masc., dl.), 'hitäti

$\leftarrow{ }^{*} \partial N-$ 'sin (adv.) 'toward me', 'tima 'darkness'

$\leftarrow *$ ěN - h'rin 'horseradish', 'simȩn (nom. sg. neut.) 'seed'

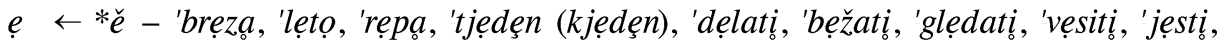
'cesta, 'mesto, 'dẹlo, nȩ'dẹla, kọ'leno, or'ẹhe (acc. pl. masc.), v'rẹmȩn (nom. sg. neut.) 'weather', 'dẹešs 'to put', 'vẹäti, nȩ'vesta 
$\leftarrow * e-$ 'zele, 'rẹku ('räku) (l-pcp., masc. sg.) 'to say'

$\leftarrow$ *z - 'mẹša 'mass', $k$ 'mẹšan (dat. pl. fem.), 'pẹs, s'nexa 'daughter-in-law', 'mẹlo ('mẹglu) (nom. sg. neut.), 'deska, g'nẹs 'today', 'vẹtȩr, 'dẹl 'forward', 'dẹlęk 'far', 'dẹš 'rain', po 'dẹži (dat. sg. masc.) 'after the rain'

$\ddot{a} \leftarrow$ *e 'nämrȩn 'I cannot', 'žägȩn 'blessing', 'žägna (gen., masc., sg.), 'näčȩ (3rd pers. sg.) 'does not want to', k'mät, 'sädęn 'seven', 'räčȩju (3p., pl), 'räkla (l-pcp., fem. sg.), 'tälę 'calf', od 'mänȩ 'from me', 'täta 'aunt', 'žäna, 'näsla (l-pcp., fem. sg.) 'to carry', 'päče (3rd pers. sg.) 'to bake', op 'šästih 'at six', 'sästra, 'mätla, 'čäsȩn, 'än 'one', 'sä 'everything'

$\leftarrow$ *e - na'räti 'to do', za'čätị 'to begin', s'räčno, 'räp, 'jätra

$\leftarrow * \check{e}-$ 'lätu (l-pcp., masc. sg.) 'to run'

$\leftarrow * a j-k^{\prime} r a ̈ j$, 'jäcę (acc. pl. fem.) 'eggs', 'jäcọn (instr. sg. fem.)

$a \leftarrow * a-p o$ 'gača $_{o}$ potica', 'nas, 'tan 'there', 'nan (pron., 1st pers. dat. pl.), b'rat 'brother', b'ratę (acc. pl. masc.), b'ratof (gen. pl. masc.), k'rava, k'ravę (acc. pl. fem.), 'jabuka (nom. sg. fem.), s'pati, g'raba 'valley', g'rabu (acc. sg. fem.), g'lažȩk 'glass', zọ'bača 'rake', 'pamętȩn, 'štala 'barn', 'mati, 'mantl 'coat', 'čabȩl 'nail', 'fatr 'father', s'ma (1st pers. du.) 'to be', 'začįmba 'zaseka'

$o \leftarrow *_{Q}-z ̌ e^{\prime} l o d e q c$, 'sọ, 'gọba, 'kọča, 'koči (loc. sg. fem.), 'tọča, 'rọbača 'shirt'

$\leftarrow *_{o}$ - 'ograt 'garden', 'ọtrọk (nom. sg. masc.), 'obät 'lunch', 'okno, 'koza, 'škoda, 'koža ('ko:uhžu), 'họdịn (1st pers. sg.), 'họdu (l-pcp., masc. sg.), 'kọ̌s, 'hosta 'woods', 'škof, 'kosa, 'stọl, 'potọk, 'tọti 'this'

$u \leftarrow * a N-$ 'kun (adj.) 'where'

$\leftarrow *^{*} o j-s^{\prime} v u j$ (poss. pron., nom. sg. masc.), 'muj (1p. pron., nom. sg. masc.), $t^{\prime} v u j$ (2nd pers. pron., nom. sg. masc.), 'kuj 'horse'

$\leftarrow *_{\partial}-$ 'sun (1st pers. sg.) 'to be'

$\leftarrow{ }^{*} N Q-s^{\prime} m u$ (1st pers. pl.) 'to be'

$\leftarrow{ }^{*} o N$ - 'duma 'at home', 'nur 'fool', 'nuš 'knife', 'nužȩ (acc. pl. masc.), 'nusin (1st pers. sg.) 'to carry', 'mutikka 'hoe', 'kunęc, 'mugli (l-pcp., masc. pl. pl.) 'to be able to', $k^{\prime}$ nuf 'button'

$\leftarrow *-u l b-s i$ 'ču 'did you hear'

$\leftarrow$ *l - 'pun, 'tukla 'apple wine', 'vuna, 'dugo, 'gučati

$\ddot{u} \leftarrow * u$ - 'püta, 'pütę (acc. pl. fem.), 'püvati 'to build', k'rüš 'bread', 'krüxa (gen., masc., sg.), 'tüu, 'žüpa 'soup', 'vütrọ, 'vüra 'hour', 'lük 'onion', 'šürc 'apron', f'küp 'together', 'kühja 'kitchen', g'rünt 'property'

$\leftarrow *_{\partial}-$ 'vün

$r \leftarrow *_{0}-{ }^{\prime} z r n o$, 'hrbȩt, $h^{\prime} m r$ (h'mru) (l-pcp., masc. sg.) 'to die'

\section{Unaccented}

$i$

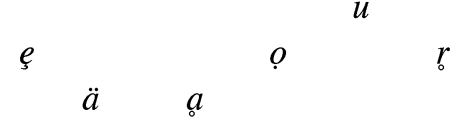

Examples

$i \quad \leftarrow$ *i s'pation, 'dẹlatị, $k$ 'mẹšs 


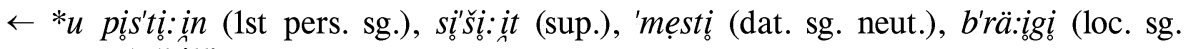
masc.) 'hill'

$\ddot{a} \leftarrow * \check{e}-$ 'hitäti, , ọbät

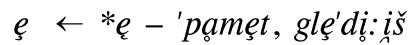

$\leftarrow$ *e - nẹ'dẹla, vẹ́ce $e: r$, 'näsẹn

$\leftarrow *_{\partial}-$ 'dẹdęk, žȩlọdẹc

$o \leftarrow{ }^{*} o-$ 'mẹsto, 'leẹto, ọ'rẹhę, 'dẹlo, vớdo:u

$u \leftarrow *_{Q}-p o^{\prime} g a c ̌ u$ (acc. sg. fem.), $k^{\prime} r a v u$ (acc. sg. fem.), g'rabu (acc. sg. fem.)

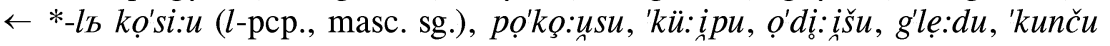

$r \leftarrow{ }^{*} r-d r^{\prime} g \rho: u \check{n}$, pr'giša (nom. sg. fem.) 'palm', or 'handful'

\section{Conclusion}

One of the key points of argumentation of each of the scholars who has thus far written about Haloze has been an attempt to place it in one of the larger dialect groups with which it shares a border. Ramovš calls attention to Haloze's Pannonian and particularly its Prlekian features. Kolarič places emphasis on features that Haloze shares with central Styrian dialects. Zorko, who has amassed a significant database, sees Haloze, especially eastern Haloze, as closer to Pannonian. Categorizing dialects in this way is important because it helps to simplify complex relationships and processes. But one problem which is often overlooked in this desire to categorize dialects is that dialects do not develop neatly according to a Stammbaum model. Dialects are rarely that simply defined, because they develop feature by feature, sharing some isoglosses with one neighboring dialect or group and other features with another dialect. Features also develop as a result of convergence, a relationship not captured by the Stammbaum model. For this reason, especially based on information from the vocalic systems of eastern and central Haloze, it may be artificial to place this dialect in either the Pannonian or Styrian base.

In many ways the northern and central vocalic systems seem quite similar. Both systems have the same number of short and long phonemes. Both systems have a fronted $\ddot{u}$ and a velarized $a$. Both have only two heights of $e$-like vowels with an asymmetry in the back of the vocalic system. This is striking in contrast to the western Haloze system of vocalic phonemes which has three height distinctions in $e$-like vowels, b'rie:za 'birch', 'pẹ:t 'five' and z've:zda 'star', and a basically symmetrical system.

The important difference between eastern and central Haloze appears when one examines the source of each of the phonemes. There are important differences in the way that the PSl. phonemes combined to form these two different systems, and it is some what problematic to derive both vocalic systems from the same Slovene dialect base.

The starting point for the processes that resulted in the vocalic system of Belavšek can be found in Rigler's common Pannonian system (1963: 43), based on the mergers which that systems presupposes, i.e., $e i r *_{r}$; $e<* e,{ }^{*} e$, ${ }^{*}$.

The mergers that are the most interesting here are those in the front of the vowel system. Here there was a merger of the reflexes of long $*_{e}, *_{\ell}$ and $*$. This is 
can be seen in the contemporary dialects of central Haloze. Long $* e, * e$ and $* z$ all give $e:$. In Rigler's Pannonian system the long *ě is a diphthong with falling sonority, and in Belavšek today the reflex of the circumflected jat is $\ddot{a}: i$. The back of the vocalic system also reflects processes common to Pannonian dialects. The reflexes of long $*_{o}$ and $*_{Q}$ merged in $Q: u$, and $* l$ took the place of the former $* u$, which itself had become fronted.

The vocalic system of Gorenjski Vrh is different in several important ways. In fact all over the east of Haloze the reflexes of PSl. long $*$ ě and long $* \partial$ have merged. They have combined into a vowel distinct from the other $e$-like vowels. In Gorenjski Vrh long $* \check{e}$ and $* \partial$ give $e:$, and long $* e$ and $* e$ have merged in $e:$. This is significant because if we are to assume the same provenience for the vocalic systems of eastern and central Haloze, in other words a Pannonian provenience, we would be forced to assume that at an early stage in eastern Haloze the reflexes of the PSl. *e, $* e$ and $* \partial$ merged, all of which had a reflex distinct from $* \check{e}$, but later $* \partial$ diverged from these and merged with $* \check{e}$. This is impossible.

A much simpler model for these mergers can be found in neighboring Kajkavian dialects which, at a very early stage, perhaps around the time when Alpine Slavic began to lose nasality, underwent the merger of long $*_{e}$ and $* \partial$. This merger of the reflexes of the long jat and the long jer is seen as a basic feature of Kajkavian dialects (Ivić 1968, Rigler 1986b). The results of this development can be seen in Haloze's closest Kajkavian neighbor, Bednja. The Bednja reflex of long * ${ }^{2}$ and $* \partial$ is $i: e$, brì:eg 'hill', dì:en 'day'. The reflexes of $* e$ and $* e$ have also merged in $a$, mà:se 'meat', šà:st 'six' (Jedvaj 1956). With that in mind, it is much less problematic to derive the vocalic system of eastern Haloze from a Common Kajkavian base like the one purposed by Vermeer in his 1983 discussion of the development of the Kajkavian vocalic system (456).

In the front of the vowel system, the contemporary situation in eastern Haloze is much like that in Bednja. The reflex of $*^{e}$ and the jers is $e:$, 'de:lan 'I work', 'de:n 'day', and the combined reflex of $* e$ and $*_{e}$ is $e:$, 'pe:t 'five', 'pe:č 'oven'. One area in which eastern Haloze seems to be different from most Kajkavian dialects, including Bednja, is the merger of $* l$ with the reflex of $*_{o}$. Eastern Haloze, like central Haloze and the rest of the Pannonian dialects, has $u$ for $* l$. This is not necessarily a problem for deriving eastern Haloze from a Kajkavian base because, according to Vermeer (1979b: 175), the Kajkavian development $* l>o$ may be a later development after an earlier stage of $* l>u$, such as is found in Pannonian and Styrian dialects.

It is likely that the eastern Haloze monophthongs $e$ : and $o$ : developed later from the rising diphthongs $i e$ and $u o$ as a result of contact with dialects with falling diphthongs. This is perhaps much like the monophthongization of ei and ou in the neighboring Slovene dialect of Središče (see Greenberg 1994). According to Tine Logar, this is the process by which we get the monophthong $e$ : and $o$ : in the Gorenjsko dialect (1996: 27). The monophthongs represent a compromise between dialects with opposing reflexes for one PSl. phoneme.

The result of this brief examination of two Haloze village dialects is that Haloze is not as internally uniform as had been thought. To Zorko's three internal isoglosses, (1) diphthongal / monophthongal vocalic system, (2) quantity oppositions and 
(3) possible tonemic oppositions, we must add (4) circumflex advancement / partial advancement, (5) merger of the reflexes of the jat and the jers and (6) development of new diphthongs such as those found in western Haloze.

\section{Figure 3: Proposed classification of Haloze sub-dialects}

\begin{tabular}{lcccccc}
\hline & diphthongs & quantity & tonemic $(?)$ & circ. adv. & $* e$ /*a merge & new diph. \\
\hline E. Haloze & - & + & + & $-/+$ & + & - \\
C. Haloze & + & + & $+/-$ & + & - & - \\
W. Haloze & + & - & - & + & - & + \\
\hline
\end{tabular}

It may be that the geographic region of Haloze does not represent one uniform dialect area, but rather the place where Styrian, Pannonian and Kajkavian dialects meet.

This phonemic description of two Haloze village dialects is only a small contribution to the body of knowledge about this region. There remains much that is a complete mystery, especially about the western end of Haloze. What we do know can add significant details to the study of the development of eastern Slovene border dialects, and the peripheral position of Haloze promises that the more we learn the more interesting the information may be.

\section{References}

Bračič, Vladimir. 1967. Vinorodne Haloze. Maribor: Založba Obzorja. - -. 1982. Gozdnate Haloze. Maribor: Založba Obzorja.

Greenberg, Marc L. 1992. Circumflex Advancement in Prekmurje and Beyond. Journal of the Society for Slovene Studies 14/1: 69-91.

- -. 1994. Archaisms and Innovations in the Dialect of Središče (Southeastern Prlekija, Slovenia). Proceedings of the 9th Biennial Conference on Balkan and South Slavic Linguistics, Literature and Folklore (ed. by George Fowler, Henry R. Cooper, Jr., and Jonathan Z. Ludwig) (= Indiana Slavic Studies 7). 91-102.

Ivić, Pavle. 1968. Procesi rasterećenja vokalskog sistema u kajkavskim govorima. Zbornik za filologiju i lingvistiku 11: 57-68.

Jedvaj, Josip. 1956. Bednjanski govor. Hrvatski dijalektološki zbornik 1: 279-330.

Kolarič, Rudolf. 1964. Haloški govor. Prace filologiczne 18/2: 395-401.

Logar, Tine. 1975. Slovenska narečja. Besedila. Ljubljana: Mladinska knjiga.

- -. 1996. Dialektološke in jezikovnozgodovinske razprave (ed. by Karmen Kenda-Jež). Ljubljana: Znanstvenoraziskovalni center SAZU, Inštitut za slovenski jezik Frana Ramovša.

Lončarić, Mijo. 1996. Kajkavsko narječje. Zagreb: Školska knjiga.

Ramovš, Fran. 1935. Historična gramatika slovenskega jezika VII: Dialekti. Ljubljana.

- -. 1936. Kratka zgodovina slovenskega jezika. Ljubljana.

Rigler, Jakob. 1963. Pregled osnovih razvojnih etap v slovenskem vokalizmu. Slavistična revija 14: $25-78$. 
- -. 1986a. Smeri glasovnega razvoja v panonskih govorih. Razprave o slovenskem jeziku (ed. by Franc Jakopin). 116-128. Ljubljana: Slovenska matica.

- -. 1986b. O slovensko-kajkavskih jezikovnih razmerjih. Razprave o slovenskem jeziku (ed. by Franc Jakopin). 129-138. Ljubljana: Slovenska matica.

Vermeer, Willem R. 1979a. Innovations in the Kajkavian Dialect of Bednja. Dutch Contributions to the Eighth International Congress of Slavists. Zagreb, Ljubljana, 1978 (ed. Jan M. Meier), 347-381. Lisse: Peter de Ridder.

- -. 1979b. Proto-Slavonic *u in Kajkavian. Zbornik za filologiju i lingvistiku 22(1): $171-177$.

- -. 1983. The Rise and Fall of the Kajkavian Vowel System. Studies in Slavic and General Linguistics 3: 439-477.

Zorko, Zinka. 1991. Vzhodni haloški govori. Nemzetközi szlavisztikai napok 4: 51-69.

- -. 1993. Daljšanje akuta v severovzhodnih slovenskih narečjih. Slavistična revija 41/1: 190-207.

Prispelo decembra 1998, sprejeto marca 1999

Received December 1998, accepted March 1999

\section{Uvodno poročilo o dialektološkem terenskem delu v Halozah}

Slovenščina je eden od najmanjših slovanskih jezikov. Govori jo malo več kot dva milijona ljudi, vendar je njen narečni zemljevid eden najbolj zapletenih in razčlenjenih v Evropi. Kljub težavam pri dokumentiranju in razčlenjevanju takega raznovrstnega narečnega sistema, je večina delov, ki sestavljajo to zapleteno celoto, že zbranih (Ramovš 1935, Rigler 1963). Vseeno pa so v slovenski narečni podobi še nekatere vrzeli, za katere je vzrok bodisi v pomanjkanju podatkov ali v nezanesljivih opisih. Ena od teh vrzeli so govori Haloz, majhnega, gričevnatega področja ob slovenski vzhodni meji. Pričujoča razprava prinaša osnovni fonološki opis dveh značilnih haloških govorov, enega iz vzhodnega (Gorenjski Vrh) in enega iz osrednjega dela (Belavšk). Te podatke je avtor uporabil v kratki obravnavi zgodovinskega izvora teh narečnih sistemov.

Izvor samoglasniških fonemov govora vasi Belavšek se najde $\mathrm{v}$ Riglerjevem splošnem panonskem sistemu (1963: 43), temelječem na sovpadih, ki jih ta sistem predpostavlja $\left(e i<* \check{e} ; e<* e,{ }^{*} e, * \partial\right)$. Najzanimivejši sovpadi so sovpadi sprednjih samoglasnikov. Tu so sovpadli refleksi dolgih $* e, *_{e}$ in $*$. To je razvidno iz današnjih osrednjehaloških govorov. Dolgi ${ }^{*} e,{ }^{*} e$ in ${ }^{*} \partial$ so vsi dali $e .$. V Riglerjevem panonskem sistemu je dolgi jat dvoglasnik s padajočo zvočnostjo; $v$ današnjem govoru

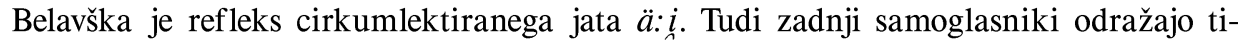
pične panonske procese. Refleksa dolgega $*^{o}$ in $*_{Q}$ sta sovpadla $\mathrm{v} Q: u$ in ${ }^{*} l$ je nadomestil * $u$, ki se je pomaknil naprej.

V samoglasniškem sistemu Gorenjskega Vrha je nekaj pomembnih razlik. Dejansko sta refleksa psl. dolgega $* \check{e}$ in dolgega *ə v celotnem vzhodnem delu Haloz sovpadla. Združila sta se v samoglasnik, ki se razlikuje od drugih $e$-jevskih samo- 


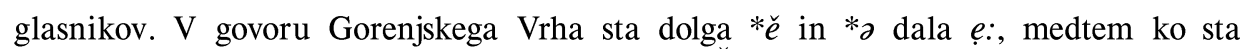
dolga *e in *e sovpadla $\mathrm{v} e:$. To je pomembno. Č namreč domnevamo isti izvor za samoglasniška sistema osrednjih in vzhodnih Haloz, tj. panonski izvor, potem moramo predpostavljati, da so $\mathrm{v}$ vzhodnih Halozah refleksi psl. *e, *e in *a zgodaj sovpadli, da so vsi imeli refleks, ki se je razlikoval od *̌e, vendar se je *ə kasneje oddaljil od tega razvoja in sovpadel $\mathrm{z} * e ̌$. To se zdi zelo malo verjetno. $\mathrm{S}$ tega stališča je veliko manj problematično izvajati samoglasniški sistem vzhodnih Haloz iz skupne kajkavske osnove, ki jo je predlagal Vermeer v svoji razpravi iz 1.1983 o razvoju kajkavskega samoglasniškega sistema (456).

Pomemben podatek, ki izhaja iz te raziskave dveh haloških govorov, je, da haloško narečje notranje ni tako enotno, kot se je mislilo doslej. Trem notranjim izoglosam Zorkove (1. enoglasniški/dvoglasniški samoglasniški sistem, 2. kolikostna nasprotja in 3. možna tonemska nasprotja) je treba dodati še 4. pomik cirkumfleksa / delni pomik, 5. sovpad refleksov jata in polglasnika; in 6. razvoj novih dvoglasnikov, podobnih tistim, ki se najdejo v zahodnohaloških govorih. Možno je, da zemljepisno pokrajina Haloze ne predstavlja enotnega narečnega področja, ampak prostor, kjer se stikajo štajerski (zahodne Haloze), panonski (osrednje Haloze) in kajkavski (vzhodne Haloze) govori.

\section{Preliminary Report on Dialectological Fieldwork in Haloze, Slovenia}

The Slovene language is one of the smallest of the Slavic family. It is spoken by somewhat more than two million people, and yet it has one of the most complex and variegated dialect maps in Europe. Notwithstanding the difficulties involved in documenting and analyzing such a diverse dialect system, most of the major pieces to this puzzle are in place (Ramovš 1935, Rigler 1963). Still, there are some holes in the Slovene dialect picture which are the result of either a lack of information or unreliable descriptions. One such gap is the dialect area of Haloze, a small, hilly region on Slovenia's eastern border. This paper provides a basic phonemic description of two representative Haloze village dialects, one from the east, Gorenjski Vrh, and one from the center, Belavšek. This data is then used in a brief discussion of the historical provenience of these dialect systems.

The origin of the vocalic phonemes of Belavšek can be found in Rigler's common Pannonian system (1963: 43), based on the mergers which that system presupposes, $\left(e i<*_{e}\right.$; $\left.e<* e, * e, * \partial\right)$. The mergers that are the most interesting here are those in the front of the vowel system. Here there was a merger of the reflexes of long $* e, *_{e}$ and $* \partial$. This can be seen in the contemporary dialects of central Haloze. Long $* e, * e$ and *z all give $e:$. In Rigler's Pannonian system the long *ě is a diphthong with falling sonority, and in Belavšek today the reflex of the circumflected jat is $\ddot{a}: i$. The back of the vocalic system also reflects processes common to Pannonian dialects. The reflexes of long $*_{o}$ and ${ }^{*} Q$ merged in $Q: u$, and $* l$ replaced $* u$, which had fronted.

The vocalic system of Gorenjski Vrh is different in several important ways. In fact all over the east of Haloze the reflexes of PSl. long * They have combined into a vowel distinct from the other $e$-like vowels. In Gorenjski 
Vrh long $* \check{e}$ and $* \partial$ give $e:$, and long $* e$ and $* e$ have merged in $e$. . This is significant because, if we were to assume the same provenience for the vocalic systems of eastern and central Haloze, in other words a Pannonian provenience, we would need to assume that at an early stage in eastern Haloze the reflexes of the PSl. ${ }^{*} e,{ }^{*}$ and *a merged, all of which had a reflex distinct from *ěe, but later *z diverged from these and merged with $* \check{e}$. This is impossible. Keeping that in mind, it is much less problematic to derive the vocalic system of eastern Haloze from a Common Kajkavian base like the one proposed by Vermeer in his 1983 discussion of the development of the Kajkavian vocalic system (456).

One important bit of information that arises from this examination of two Haloze village dialects is that Haloze is not as internally uniform as was thought. To Zorko's three internal isoglosses, (1) diphthongal/monophthongal vocalic system, (2) quantity oppositions and (3) possible tonemic oppositions, we must add (4) circumflex advancement/partial advancement, (5) merger of the reflexes of the jat and the jers and (6) development of new diphthongs such as those found in western Haloze. It may be that the geographic region of Haloze does not represent one uniform dialect area, but rather the place where Styrian (western Haloze), Pannonian (central Haloze) and Kajkavian (eastern Haloze) meet. 